\title{
Leprosy in British India, 1860-1940: Colonial Politics and Missionary Medicine
}

\author{
SANJIV KAKAR*
}

\section{Introduction}

Leprosy has received scant attention in discussions of health in colonial India, which have focused on imperial and colonial politics, and on state intervention. ${ }^{1}$ Nongovernmental efforts, of which leprosy offers an important instance, have been neglected. ${ }^{2}$ In this article I discuss the dissemination of western medicine for leprosy in colonial India, which was largely the work of Christian missionaries. David Arnold has pointed out that "the extent to which missionaries were successful disseminators of Western medical ideas and practices in India ... has yet to receive serious scholarly attention." 3 Discussion of the work of medical missionaries with leprosy sufferers also opens up for further examination the processes by which western medicine took root in the sub-continent.

All too often western medicine in India has been read as a scientific intervention, especially from the 1870 s onwards with the advent of germ theories. In many ways leprosy was unique. For much of the nineteenth century western medicine was characterized by ignorance about causation and transmission of the disease, and had no cure for it; there was also much prejudice against leprosy in the West, which intruded into

*Sanjiv Kakar, MPhil, College of Vocational Studies, University of Delhi; address for correspondence: Bungalow 31, Nizamuddin East, New Delhi 110013, India. Tel.: 91114619 627; Fax: 91114633623 (marked for Sanjiv Kakar).

The author acknowledges with gratitude the support of the Wellcome Trust, the Charles Wallace (India) Trust, and the Indian Council of Social Sciences Research. Portions of this paper have been read at the Wellcome Institute for the History of Medicine, London, in April 1994 (History of Science and Medicine seminar series) and at the Institute of Commonwealth Studies, University of London, in May 1994 (Health and Empire postgraduate seminar). I am grateful for comments by participants. I also acknowledge a great debt to the referees.

\footnotetext{
1 This contrasts with the volume of historical study on leprosy elsewhere; see Zachary Gussow, Leprosy, racism and public health: social policy in chronic disease control, Boulder and London, Westview Press, 1989; Gussow's scattered comments on leprosy in India, mostly contained in a chapter on
}

Hawaii (pp. 85-110) constitute the major historical discussion to date. See also C De. F W Goonaratna, 'Some historical aspects of leprosy in Ceylon during the Dutch period, 1658-1796', Med. Hist. 1971, 15: 68-78; W S Davidson, Havens of refuge: a history of leprosy in western Australia, Nedlands, University of Western Australia Press, 1978; Suzanne Saunders, 'A suitable island site': leprosy in the Northern Territory and the Channel Island leprosarium 1880-1955, Darwin, Historical Society of the Northern Territory, 1989.

2 Two major studies on health in colonial India are: David Arnold, Colonizing the body: state medicine and epidemic disease in nineteenth-century India, Berkeley, University of California Press, 1993, and Mark Harrison, Public health in British India: Anglo-Indian preventive medicine 1859-1914, Cambridge University Press, 1994. Maneesha Lal 'The politics of gender and medicine in colonial India: the Countess of Dufferin's Fund, 1885-1888', Bull. Hist. Med., 1994, 68: 29-66, discusses voluntary efforts to take western medicine to Indian women, and is a happy exception.

${ }^{3}$ Arnold, op. cit., note 2 above, p. 244. 


\section{Sanjiv Kakar}

the medical perspective, and religious beliefs about leprosy and medieval European practices lingered on. Leprosy's continuing incurability bred an openness towards indigenous treatments, an historical anomaly during this period. Because of a strong missionary involvement alongside the disinterest of the colonial state in India, Christian missionaries acquired a commanding position in the dissemination of western medicine for leprosy, and their perspectives modified further the treatments dispensed to patients. Finally, the responses of Indian patients towards western medicine and its institutions were influenced by the long tradition of persecution of leprosy patients in India, as well as by specific practices in leprosy asylums, and, in the process of interaction, western medicine was moulded further. ${ }^{4}$

Section I outlines the evolution of official policy on leprosy in colonial India, and the pressures, global, official, medical, and missionary, which went into placing it squarely within the voluntary sector. Within this wider context, section II examines the missionary leprosy asylums as western medical institutions. I also discuss here the impact of tropical medicine on the leprosy asylum, which I read as a liberating medical intervention. ${ }^{5}$ In the Conclusion, I review the nature and the limits of medical intervention in leprosy in India during the colonial period. Oral history is used to highlight discussion on western medicine for leprosy and Indian responses to it.

\section{I}

\section{The Formation of an Official Policy on Leprosy}

The formation of policy on questions of health in colonial India was rarely a matter of medicine alone. The areas of highest priority which concerned the colonial state have been identified by Radhika Ramasubban and others as being the health of the army, the European population, and the protection and pursuit of mercantile interests; the health of the indigenous people was peripheral, except when vital interests were threatened. ${ }^{6}$ As leprosy was not deemed a threat by the Government of India, it was resistant to pressures for greater intervention. The core issue was whether leprosy endangered public health; the

\footnotetext{
${ }^{4}$ For Indian perceptions of leprosy see $\mathrm{W}$ Crooke, The popular religion and folklore of northern India, Westminster, Archibald Constable, 1896, pp. 91, 137, 169; Kriparam Sarma, Leprosy and its treatment, Howra, published by the author, 1911; Sanjiv Kakar, The patient, the person: empowering the leprosy patient, New Delhi, Danlep, 1992; idem, 'Leprosy in India: the intervention of oral history', Oral Hist. 1995, 23(1): 37-45.

${ }^{5}$ Michael Worboys has discussed tropical medicine as "an important element in the ideology of progressive imperialism". Michael Worboys, 'Tropical diseases', in W F Bynum and Roy Porter (eds), Companion encyclopedia of the history of medicine, 2 vols, London and New York, Routledge, 1993, vol. 1, pp. 512-36, on p. 521. I examine the impact of tropical medicine upon leprosy institutions in India, rather than its imperial origins, which
}

offers another perspective. See also Michael Worboys, 'The emergence of tropical medicine: a study in the establishment of a scientific specialty', in Gerald Lemaine, et al. (eds), Perspectives on the emergence of scientific disciplines, The Hague, Mouton, 1976, pp. 75-98; idem, 'Science and British colonial imperialism, 1895-1940', DPhil thesis, University of Sussex, 1979; Helen Joy Power, 'Sir Leonard Rogers FRS (1868-1962): tropical medicine in the Indian Medical Service', PhD Thesis, University of London, 1993.

${ }^{6}$ Radhika Ramasubban, 'Imperial health in British India, 1857-1900', in Roy Macleod and Milton Lewis (eds), Disease, medicine, and empire: perspectives on western medicine and the experience of European expansion, London and New York, Routledge, 1988, pp. 38-60. 
leprosy patient was merely, to use Sander Gilman's phrase, "the image of the disease anthropomorphized".?

Leprosy in India achieved visibility in the second half of the nineteenth century, largely due to its greater visibility internationally. This coincided with an overall concern in the status of public health in India following the take-over by Britain of administrative authority from the East India Company. During the 1860s, the first leprosy census took place, which estimated that there were 99,073 persons suffering from leprosy in British India. ${ }^{8}$ The first major investigation into leprosy in India was begun by the Royal College of Physicians in 1862 almost by default. In the wake of allegations of a leprosy epidemic in the West Indies they had been asked to advise whether segregation of leprosy patients was necessary. Their wider appeal for information revealed the extent of leprosy in India.

The Report on leprosy by the Royal College of Physicians (1867) drew considerable criticism for its conclusion that the disease was hereditary. Because it was "in favour of the non-contagiousness of leprosy", it considered confinement of patients to be unnecessary. ${ }^{9}$ This belief in hereditary transmission drew heavily upon Danielssen and Boeck, researching in Bergen, Norway, whose monumental work (1848) had laid the foundation for the scientific study of leprosy. ${ }^{10}$ But debate on how transmission occurred was not stilled; it drew also upon the increasing acceptance of the germ theory of disease, especially from 1873/4, when Armauer Hansen discovered the bacillus, Micobacterium leprae, in the tissues of leprosy patients. He posited this as the causative agent of leprosy. According to Irgens, "Armauer Hansen concluded that leprosy was a specific disease, representing a nosological entity with a clearly definable etiology, and not simply a degenerative condition resulting from various causes."11 Hansen rejected heredity, and held leprosy to be a contagious disease; he advocated confinement of patients as the preventive measure, and legislation was enacted in Norway in 1885 for the compulsory confinement of patients who did not conform to a strict regimen of isolation in their homes. ${ }^{12}$ But Hansen was unable to establish how transmission occurred: "I don't know the way in which leprosy is communicated or transferred from a leper to a sound person, but I am most inclined to believe that it is done by a sort of inoculation . . . this is only hypothesis."13 Koch's postulates remained unfulfilled, and Hansen's theories were questioned by those who continued to hold onto earlier notions that leprosy was hereditary, or was caused by dietary and climatic factors, as well as by those sympathetic

\footnotetext{
${ }^{7}$ Sander L Gilman, Disease and representation: images of illness from madness to AIDS, Ithaca, Cornell University Press, 1988, p. 2.

${ }^{8}$ Cited in Phineas S Abraham, 'Leprosy: a review of some facts and figures', Trans. Epidemiol. Soc. Lond., n.s., 1888-89, 8: 118-51, on p. 125 . For comment on the accuracy of census estimates, see note 22 below.

${ }^{9}$ Report on leprosy by the Royal College of Physicians, London, Eyre and Spottiswoode, 1867, p. vii. For a discussion of this see Lancet, 1867, i: 189, and $B r$. med. J., 1867, i: 335.

${ }^{10} \mathrm{D}$ C Danielssen and William Boeck, Traité de
}

\author{
la spédalskhed ou éléphantiasis des Grecs, Paris, J B \\ Baillière, 1848. \\ ${ }^{11}$ Lorentz M Irgens, 'Leprosy in Norway: an \\ interplay of research and public health work', Int. J. \\ Leprosy, 1973, 41(2): 189-98, on p. 194. \\ 12 In actual fact this was rarely enforced; see \\ Leprosy in India: report of the Leprosy Commission \\ in India, 1890-91, Calcutta, Supt. of Govt. Print., \\ 1892, pp. 417-18; also H P Lie, 'Why is leprosy \\ declining in Norway?', Trans. R. Soc. Trop. Med. \\ Hyg., 1929, 22(4): 357-66. \\ ${ }_{13}$ Letter from Hansen, J. Leprosy Investigation \\ Committee, 1891, no. 2, pp. 63-6, on p. 64.
}




\section{Sanjiv Kakar}

to bacteriology, who held that the degree of contagion had not been established sufficiently to warrant confinement. ${ }^{14}$

During this period, missionary interest in leprosy developed and the general public was targeted for subscriptions, which contributed to sustaining public concern. In 1874 Wellesley Bailey founded the Mission to Lepers in India, which was to become the major organization concerned with leprosy; by 1893 the Mission to Lepers had 10 asylums and supported 8 others; in 1899 it maintained 19 asylums, and aided many others. Missionary publications on leprosy drew on Biblical representations, and Wellesley Bailey's comment is typical of this discourse: "The utter helplessness and dependence of these folks on others is a continual picture of the way sinners have to come to God and get His blessing". ${ }^{15}$ Gussow has commented: "To a mind attuned to the Old Testament, leprosy is abomination, a matter of ritual uncleanliness. For those who believe in the New Testament, the stories of Christ miraculously curing the lepers become metaphors for divine salvation". ${ }^{16}$ Missionary activity imprinted the specifically Christian representation of leprosy in the public mind, and Gussow has discussed how historically "this care and treatment evolved into a separatist tradition."17

Amid growing acceptance of the communicability of leprosy, in 1887 and again in 1889 the Royal College of Physicians recommended another investigation. Public and medical concern were heightened by fears of a leprosy epidemic in Hawaii, especially in 1889 , following the death from leprosy in Molokai of Father Damien de Veuster, a Belgian priest who had elected to spend his days with the leprosy patients isolated on this island. To many his death proved that leprosy was indeed contagious, and this led to panic reactions in the West, with calls for compulsory confinement of patients as the only means to stem the onslaught of the disease. The situation in England at this moment was particularly relevant for its impact on imperial and colonial policy, though within a decade leprosy was to fade from public imagination. A A Kanthack summed up the mood of the 1880 s in England in The Practitioner:

Unfortunately the whole question of leprosy and its prevention has been surrounded with much feeling and sentiment, and has not always been approached with the necessary impartiality and candour. Laymen have too often been allowed to pour out their harrowing stories, and have been listened to with too much credulity. ${ }^{18}$

There was a spate of publications by medical and non-medical writers alike, many of whom represented leprosy as an imperial danger, and called for the confinement of all patients. ${ }^{19}$ Shortly after Father Damien's death, a National Leprosy Fund was instituted,

\footnotetext{
${ }^{14}$ For instance Jonathan Hutchinson, On leprosy and fish-eating, London, Archibald Constable, 1906, argued that leprosy was transmitted through the eating of rotten fish; see comment on this in Sir Leonard Rogers and Ernest Muir, Leprosy, Bristol, John Wright, 1925, pp. 61-2.

15 Wellesley C Bailey, The lepers of our Indian empire, London, John F Shaw, 1892, p. 80.

16 Gussow, op. cit., note 1 above, p. 3.

17 Ibid., p. 21. But separatism was sustained by the medical discourse as well, which did not derive from missionary activity.
}

\footnotetext{
18 A A Kanthack, 'Notes on leprosy in India', The Practitioner, 1893, 50: 463-72, on p. 463.

${ }^{19}$ H P Wright, Leprosy and segregation, London, Parker, 1885; Surgeon-Major R Pringle, 'The increase of leprosy in India; its causes, probable consequences, and remedies', Trans. Epidemiol. Soc. Lond., 1888-89, 8: 152-63; Sir Morell Mackenzie, The dreadful revival of leprosy, Wood's Medical and Surgical Monographs, vol. v, New York, 1890; Robson Roose, Leprosy and its prevention, as illustrated by Norwegian experience, London, H K Lewis, 1890; George Thin, Leprosy,
} 
under the patronage of the Prince of Wales, whose activities included the appointment of a Leprosy Commission for India. This had one member each from the Royal College of Physicians, the Royal College of Surgeons, and the Executive Committee of the National Leprosy Fund. ${ }^{20}$ This major investigation into leprosy in India, like its predecessor, that of the Royal College of Physicians, was provoked by external factors.

Ironically, during the $1880 \mathrm{~s}$ and $1890 \mathrm{~s}$, when fears about leprosy were greatest, the numbers of patients in India declined. In 1881 there were an estimated 120,000 leprosy patients, while the estimate for 1891 was down to 110,000 probably due to famine deaths. ${ }^{21}$ No doubt these figures were on the low side, yet there was nothing to suggest that leprosy was on the increase. ${ }^{22}$

The Leprosy Commission's Report represented the most exhaustive investigation of the century into leprosy in India. Its conclusion that leprosy was not hereditary was in tune with medical thinking at the time, but the view that "under the ordinary human surroundings the amount of contagion which exists is so small that it may be disregarded" provoked criticism from medical and lay persons alike. ${ }^{23}$ The furor which followed its publication and the virtual rejection of the sections on segregation by some members of the Special Executive Committee, appointed to review the conclusions, illustrated a widespread commitment to segregation and confinement. Members of the Special Committee included the Under-Secretary for India (Chairman), and a nominee each from the Royal College of Physicians and the Royal College of Surgeons. The Special Committee declared that it "would be sorry if the Government of India were encouraged by the Report of the Commissioners to refrain from taking the necessary steps in the direction of such segregation of lepers as may be found possible."24 However some members of the Special Committee dissented, siding with the Leprosy Commission in saying that "the spread of leprosy by contagion is not sufficient to justify the compulsory segregation of lepers"; dissenting voices included Jonathan Hutchinson, the nominee of

London, Percival, 1891; William Tebb, The recrudescence of leprosy and its causation: $a$ popular treatise, London, Swan Sonnenschein, 1893. Tebb made some comments on the yet unpublished Leprosy Commission Report, which earned a scathing critique by A A Kanthack in the Br. med. J., 1893, i: 489; George Newman, Edward Ehlers, S P Impey (eds), Prize essays on leprosy, London, New Sydenham Society, 1895.

${ }^{20}$ Members were Beaven Rake, whom Sir Leonard Rogers described as "a well-known leprologist ... . with very strong anti-contagionist views", George A Buckmaster and Alfred A Kanthack; Rogers and Muir, Leprosy, op. cit., note 14 above, p. 66. The Government of India nominated two members, Arthur Barclay and Samuel J Thomson, both of the Indian Medical Service.

${ }^{21}$ These are census estimates, cited in the Leprosy Commission Report, op. cit., note 12 above, p. 150.

${ }^{22}$ Dr Henry Van Dyke Carter of the IMS conducted independent investigations into the incidence of leprosy in western India, and found that the variation between the official figures and his own was large. See Surgeon Henry Vandyke Carter, 'Report on the prevalence and characters of leprosy in the Bombay Presidency, India; based on the official returns of 1867', Trans. med. Physical Soc. Bombay, 1872, pp. 74-248.

${ }^{23}$ Leprosy Commission Report, op. cit., note 12 above, p. 289.

${ }^{24}$ Papers relating to the treatment of leprosy in India, from 1887-95, selections from the records of the Govt. of India, Home Dept, Calcutta, Supt. of Gov. Print., 1896, p. 304, hereafter Papers. See discussion on the Leprosy Commission Report and the Special Committee in Lancet, 1893, i: 1070-1, and $B r$. med. J., 1893, ii: 135-8. For a defense of the Leprosy Commission by one of its members, see Kanthack, op. cit., note 18 above. On the enduring prejudice against leprosy see Zachary Gussow and George S Tracy, 'Stigma and the leprosy phenomenon: the social history of a disease in the nineteenth and twentieth centuries', Bull. Hist. Med., 1970, 44: 425-49. 


\section{Sanjiv Kakar}

the Royal College of Surgeons, and four members of the executive committee of the National Leprosy Fund. ${ }^{25}$ As a medical document, the Report of the Leprosy Commission was far ahead of its time; the British Medical Journal termed it "one of the landmarks in the history of leprosy" and medical developments later in the century were to support its rejection of segregation. ${ }^{26}$ But global fears and other non-scientific factors continued to haunt medical opinion, and the First International Leprosy Congress at Berlin (1897) concluded that "every leper is a danger to his surroundings" and recommended segregation; it also declared leprosy to be "virtually incurable". 27 Segregation was reaffirmed in 1909 at the Second International Leprosy Congress held in Bergen.

The Government of India, however, chose to disregard the Special Committee and accepted the verdict of the Leprosy Commission on contagion. Invoking statistics to argue that leprosy was not on the increase, the Governor General in Council ruled that "Legislation for the compulsory detention of lepers will ... only be justifiable when it has been established beyond reasonable doubt that the disease is contagious". ${ }^{28}$ This was entirely in tune with the official attitude on leprosy, which was to appease pressure groups whilst incurring minimal expense, while the selective use of medical opinion was a standard means of legitimizing political choices. Voluntary activity in leprosy was supported, but since 1882 the state had declared that it was unable to commit itself to anything more, because of "other claims on the public revenues." 29 The differences within the colonial establishment, official and medical, were most evident in the case of leprosy, where the usual closing of ranks during epidemic outbreaks did not occur. Regional pressures produced solutions which did not necessarily conform to official policy. In Bombay, European and Indian elite opinion exerted continuous pressure for legislation which would end the congregation of vagrant leprosy patients in the city, and sanitary opinion concurred. ${ }^{30}$ Efforts by Indian elite groups in Bombay, especially the Parsis, working with pro-segregation figures like Dr Henry Vandyke Carter, an officer of the IMS, resulted in the establishment of several leprosy asylums in the region. The Bombay government gave in to public pressure by amending municipal by-laws and declaring leprosy to be "an infectious disease dangerous to life", even as the central government denied this. ${ }^{31}$ But there was never enough space in the Bombay leprosy asylums to accommodate the homeless patients. Similar situations occurred in other provinces.

At the all-India level, in 1889 the government had toyed with a draft bill on confinement, which had been widely circulated for comments to a wide cross section of the population, including colonial officials, European and Indian medical men, some native chiefs, and other groups such as learned and scientific societies. Their responses suggested that partial confinement was not a solution to the problem of leprosy transmission. ${ }^{32}$ But urban elite groups had to be appeased. ${ }^{33}$ This resulted in the Lepers Act of 1898, the major legislation on leprosy of the colonial period, which represented a

\footnotetext{
25 Papers, op. cit., note 24 above, p. 306.

${ }^{26}$ Br. med. J., 1893, 1: 968.

${ }^{27}$ Quoted in Br. med. J., 1897, ii: 1273.

28 Govt. of India communication to Viscount Cross, Secretary of State for India, 24 Dec. 1890, Papers, p. 299.

29 Bombay Government Resolution, 1882. Bombay Gazette, 1882, Part 3 (Supplements),
}

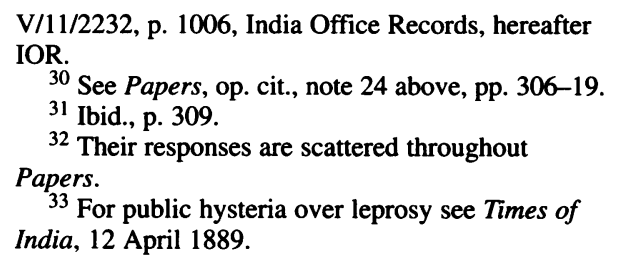




\section{Leprosy in British India, 1860-1940}

typically colonial solution to a health problem which did not touch colonial interests. It facilitated, albeit only in leprosy asylums, the forcible "segregation and medical treatment of pauper lepers"; it covered "any person suffering from any variety of leprosy in whom the process of ulceration has commenced". 34 Here a medical definition of leprosy, which equated vagrancy and ulceration with contagion, was produced to comply with colonial interests. The Act went against the grain of the Leprosy Commission, whose report the government had accepted. Vagrant patients with ulcers were an unpleasant sight to urban elite groups, Indian and European; in March 1895 the Government of India resolved that the matter "has an administrative as well as a medical aspect" and that "the loathsomeness of the disease" justified certain measures. ${ }^{35}$ This argument underwrote the definition of leprosy which the Act produced, which had a political rather than a medical genealogy.

The Act was applicable only where notifiable (in Bombay this was not done until 1911), so its impact was limited, especially as financial support for institutions was not forthcoming. But it gave official recognition to the asylums as the institutions for leprosy and channelled grants-in-aid to them. Medical intervention took place within these parameters. The asylums, mostly missionary managed, offered a particular kind of medicine and medical practice; according to Gussow "church affiliated agencies have dominated the field of leprosy work worldwide to the present day". ${ }^{36}$ Some statistical data are useful here. In 1911 there were some 73 asylums catering for about 5,000 patients, or 4.7 per cent of the total. ${ }^{37}$ By 1916 the number of asylums had risen to $81 .{ }^{38}$ In 1921 , of 94 leprosy asylums for the whole of India, 73 were in areas under direct British rule, the majority maintained or supported by Christian missions. ${ }^{39}$ The next section examines the leprosy asylum as a medical institution.

\section{II}

\section{Medicine, Missionaries and the Leprosy Asylum}

Missionary care for leprosy was a complex interaction between medicine, medieval practices, and religious observances, all of which were modified by the responses of patients. C Peter Williams' separate spheres' argument does not adequately consider this:

Victorian evangelicalism tended to see a sharp body/soul divide. The soul must be saved for eternity. The body remained part of the vale of tears . . . Consequently evangelical missionary societies employed doctors on the understanding that spiritual work was primary. ${ }^{40}$

For missionaries the leprosy asylum was the favoured institution. This had a pre-history in medieval Europe, where it "combined the functions of prison, monastery and

\footnotetext{
${ }^{34}$ Lepers Act, also known as Act No. 111 of 1898. V/8/62, IOR.

35 Papers, op. cit., note 24 above, p. 365.

${ }^{36}$ Gussow, op. cit., note 1 above, p. 21.

37 Census of India, 1911, Part 1, Calcutta, 1913, p. 335.

${ }^{38}$ For additional data see Home Medical A, August 1917, Nos. 36-61, National Archives of India, New Delhi, hereafter NAI.

${ }^{39}$ See Frank Oldrieve, India's lepers; how to
}

rid India of leprosy, London, Marshall, 1924, pp. 53-5; Robert G Cochrane, Leprosy in India: $a$ survey, London, World Dominion Press, 1927, pp. 5-14.

${ }^{40} \mathrm{C}$ Peter Williams, 'Healing and evangelism: the place of medicine in later Victorian protestant missionary thinking', in W J Sheils (ed.), The church and healing, Oxford, published for the Ecclesiastical History Society by Basil Blackwell, 1982, pp. $271-87$, on p. 280. 
almshouse, and responded to the need for seclusion and segregation". ${ }^{41}$ Initially leprosy homes were more in the nature of sanctuaries than medical institutions; Wellesley Bailey described one such in Ambala, in 1869: "To my surprise I found it was but a little way off, just on the other side of the road from my house .. . The asylum consisted of three rows of huts under some trees". ${ }^{42}$ Diagnosis was mainly the work of lay persons, and misdiagnosis remained a possibility, as confusions with leucoderma and syphilis were common. ${ }^{43}$ The evolution of the leprosy asylum in India as a medical institution followed a similar development in Norway. Until the middle of the nineteenth century no medical services weife available for leprosy patients in asylums in Norway. ${ }^{44}$ But, following the efforts of Danielssen and Boeck, when Dr Vandyke Carter visited Norway on a tour of leprosy institutions in the early 1870s, he found "a qualified surgeon is in medical charge of each asylum". ${ }^{45}$ The impact of the changes in India was uneven, but by 1889 the leprosy asylum was recognized as a western medical institution, and the Leprosy Commission turned to asylums for information on leprosy and its treatment. ${ }^{46}$

Most of the asylums which supplied data to the Leprosy Commission referred to medical facilities, ${ }^{47}$ which suggested that medical services were an important part of the asylum culture, a view echoed by missionary-sponsored publications. ${ }^{48} \mathrm{But}$, as I shall argue, in India the well-being and comfort of leprosy patients were neglected long after a similar situation had been corrected in Norway.

As medical practices, separation of leprosy patients, confinement, and segregation of the sexes in asylums call for some discussion. On the issue of confinement western medicine was a house divided. For those who believed that leprosy was hereditary, confinement of all patients and separation of the sexes were means of breaking the chain

${ }^{41}$ S G Browne, 'Some aspects of the history of leprosy: the leprosie of yesterday', Proc. $R$. Soc. Med., 1975, 68(8): 485-93, on p. 489. See also idem, 'Leprosy: the christian attitude', Int. J. Leprosy, 1963, 31(2): 229-35; Saul Nathaniel Brody, The disease of the soul: leprosy in medieval literature, Ithaca, Cornell University Press, 1974; Peter Richards, The medieval leper and his northern heirs, Cambridge, D S Brewer, 1977.

${ }^{42}$ Quoted in A Donald Miller, An inn called welcome: the story of the Mission to Lepers 1874-1917, London, Mission to Lepers, 1965, pp. $10-11$.

${ }^{43}$ See 'Leprosy: reports of local governments, 1875-78', V/27/854/4, IOR; Phineas S Abraham, 'Analysis of 118 cases of leprosy in the Tarntaran Asylum (Punjab), reported by Gulam Mustafa, Assistant Surgeon', Trans. Epidemiol. Soc. Lond., n.s., 1889-90. 9: 52-69.

44 This point is made in a poem by Peder Olsen Feidie, a patient at St George's Hospital for Lepers, Bergen, from 1832 to 1849 ; see Richards, op. cit., note 41 above, p. 158-61. Also idem, 'Leprosy in Scandinavia', Centaurus, 1960-61, 7: 101-33, especially pp. 108-15. This neglect of the patients was the result of the emphasis on the eradication of leprosy as a priority, spelled out in the Lancet in
1872: "it is to the great question of the extinction of leprosy, and not merely to the alleviation of the sufferings of the actually leprous, that the mind of the philanthropist and the legislator should be finally directed", Lancet, 1872, ii: 269.

45 Henry Vandyke Carter, Report on leprosy and leper-asylums in Norway; with references to India, London, Eyre and Spottiswoode, 1874, p. 13.

46 Some hospitals offered medical treatment for leprosy, others admitted leprosy patients only if they suffered from concurrent ailments, others not at all; see the Royal College of Physicians Report, op. cit., note 9 above, p. xlix; for data on provinces see Home Medical A, December 1898, Nos. 43-61, NAI.

${ }^{47}$ Leprosy Commission Report, op. cit., note 12 above, p. 377-98.

48 Bailey, op. cit., note 15 above; and idem, $A$ glimpse at the Indian mission field and leper asylums in 1886-7, 2nd ed., London, John Shaw, 1892; George Jackson, Lepers: thirty-six years' work among them: being a history of the Mission to Lepers in India and the East, 1874-1910, London, Marshall, 1910; Patrick Feeny, The fight against leprosy, London, Elek, 1964; Miller, op. cit., note 42 above; Cyril Davey, Caring comes first; the story of the Leprosy Mission, London, Marshall Pickering, 1987. 
of infection. But there were medical problems in implementation, quite apart from the social dislocation and economic aspects of segregation. T R Lewis and D D Cunningham, who supported the heredity theory, wrote in 1877 of

serious and almost insurmountable difficulties ... it would not be sufficient merely to confine those suffering from developed disease, but all those who might in any degree be supposed to be hereditarily disposed towards it ... But had all those predisposed to be secured, how and by whom could the existence of predisposition be determined? ... it is quite uncertain for how long-for how many generations, the disposition may be transmitted without giving any ostensible sign of its presence ...49

By the 1880s the issue of confinement had become entangled in discussions on the germ theory of disease, and within a climate of growing fears of leprosy epidemics, confinement gained in acceptance, and enjoyed medical support internationally. ${ }^{50}$

Missionary intervention in leprosy furthered separatism as the leprosy asylum was intrinsically exclusive, though attitudes to confinement varied. The Mission to Lepers did not enforce segregation in its own asylums, but individual asylums supported by it might. The medical beliefs of the asylum managers were only one aspect; at a conference of leprosy asylum superintendents in 1908, the Rev. J Hahn stated that "even if we could accept the findings of the Leprosy Commission as being correct, the disease is such a horrible one ... segregation must be enforced". 51 The persistence of belief in hereditary transmission also contributed to support for confinement. ${ }^{52}$

From the 1880 s, segregation increased, bypassing sanitary opinions. Vagrant patients were placed in asylums, which were removed to the outskirts of towns. So, for example, a study conducted to choose an alternative location for the Albert Victor Leper Asylum finally settled upon a site at Gobra, rejecting the views of the Sanitary Commissioner for Bengal, who in 1893 had argued that "Leper asylums in large Presidency-towns should ... be enlarged" on account of "drainage, water-supply and conservancy arrangements". 53 These developments were not welcomed by patients, particularly because of the denial of liberty which this involved. Patients often had compelling reasons to leave the asylum; to travel, to earn handsome sums by begging, or to go on pilgrimage, seeking cure by prayer and penance. An officer from the Rawalpindi asylum commented on their great mobility:

We have had in the last two years lepers from as distant places as Calicut, Tibet, Bombay, Calcutta, Madras and Afganistan. Last year we had a troupe of Bengali and United Province Lepers who stayed until it got cold and then started south ... Begging is so profitable at the time of religious festivals that the least helpless of our lepers prefer to go and beg. ${ }^{54}$

49 T R Lewis and D D Cunningham, Leprosy in India: a report, Calcutta, Supt. of Gov. Print., 1877, p. 68. For discussion favouring confinement see a series of reports by Henry Vandyke Carter, 'Memoranda on leprosy', V/27/854/3, IOR.

${ }^{50}$ In the USA, legislation on confinement was enacted in 1917; Gussow, op. cit., note 1 above, p. 22. In Hawaii, patients were segregated in Kalaupapa until the 1970s, see ibid., p. 107. In Australia's Northern Territory segregation laws were strengthened in 1931; see Saunders, op. cit., note 1 above, p. vii.

${ }^{51}$ Report of a Conference of Leper Asylum
Superintendents held at Purulia, Bengal, from 18th to 21 st February 1908 (under the auspices of the Mission to Lepers in India and the East), Edinburgh, Daren Press, 1908, p. 29.

52 See Statesman, 12 April 1928.

53 Papers, op. cit., note 24 above, p. 344.

54 Honorary Medical Superintendent, Rawalpindi Asylum, 1920, P/10838, IOR. For indigenous attitudes on healing possibilities of prayer, see the letter of Sailojananda Ojha, High Priest, Baidyanath Temple, dated 8 May 1889; Papers, op. cit., note 24 above, p. 15-16. 


\section{Sanjiv Kakar}

The religious character of the asylum, including denial of freedom of worship and mandatory Christian teaching, also produced inhospitable conditions. Missionaries tended to deny that religious teaching was forced upon patients; at the Purulia asylum, the superintendent, the Rev. J Uffman declared, "I do not allow the inmates to worship idols, nor do I require them to become converts. Every inmate is allowed to remain in his own religion" ${ }^{55}$ This view was countered by Gonesh Dutta Singh, the Minister of Local SelfGovernment for Bihar and Orissa, who visited the Purulia asylum in 1925:

Many who enter as Hindus come out as Christians ... It does not look well to make it a place of conversion. No doubt it is also a fact that they are not compelled to adopt Christianity. But the atmosphere of the asylum is such that incentive towards conversion to Christianity becomes to some extent irresistible. ${ }^{56}$

Segregation of the sexes in asylums was the product of a complex interaction between medicine, missionaries, and the colonial state, and it was widely opposed by patients. Observed in religious sanctuaries for leprosy patients in medieval Europe, the practice continued in the Norwegian leprosy hospitals even after medical intervention there in the 1850s. Medical tolerance for this reveals a strong residue of medieval and religious influences, for there was no scientific evidence that leprosy was transmitted sexually; and the small numbers of children born to patients in asylums made segregation unnecessary as a preventive measure. ${ }^{57}$ Yet separation of the sexes in asylums in India increased during the 1880 s, alongside confinement. ${ }^{58}$ Missionaries were eager to enforce this. ${ }^{59}$ Indeed, the donating public in England and Europeans in India expected segregation to be enforced. ${ }^{60}$ Governmental intervention, always a piecemeal response to pressure groups, made it mandatory in 1888 in all asylums which received government grants. ${ }^{61}$ The 1920 Calcutta Conference of Leprosy asylum superintendents reaffirmed this practice as a means of preventing births in asylums. ${ }^{62}$ The commitment to enforcing segregation could be intense; at the Naini asylum, when the new superintendent, Dr A G Noehren, arrived from the United States in 1937, he immediately implemented it, although he anticipated resistance from the inmates. ${ }^{63}$

As a religious and a medical practice, sexual segregation had a dual lineage, and the indigenous patient had to come to terms with both. In the Indian tradition it was not uncommon for a leprosy patient to be accompanied into exile, and even into the asylum, by a healthy wife. There was great resistance to segregation in the asylums, and it was another factor which deterred leprosy sufferers from seeking admission, and which also prompted escapes. Violations of the rule were often punished by excommunication for those who had converted to Christianity, which suggests that a religious rather than a medical discourse was invoked. Because of harsh conditions outside, patients tried to

55 Quoted in V/4740, IOR.

${ }^{56}$ Report of Gonesh Dutta Singh, 5 July 1925 , 111/8, The Leprosy Mission, 80 Windmill Road, Brentford, Middlesex, TW8 OHQ. I am grateful to the Director for access to the archives. Hereafter TLM.

57 See Lewis and Cunningham, op. cit., note 49 above, pp. 63-7.

58 By 1887 all asylums in the Madras presidency enforced it. For further data, see Papers, op. cit., note 24 above, p. 6 .
${ }^{59}$ Bailey, op. cit., note 48 above, p. 10.

${ }^{60}$ See Report of a Conference of Leper Asylum Superintendents, op. cit., note 51 above, pp. 20, 64 .

${ }^{61}$ Home Dept Resolution, 26 September 1888;

Home Medical, July 1889 Nos. 26-30, NAI.

62 See discussion in Rogers and Muir, op. cit., note 14 above, p. 132.

${ }^{63}$ Letter from Noehren to Mission to Lepers, 17 March 1937, 110/9, TLM. 
escape to asylums where segregation had been abandoned. The most famous, almost notorious, asylum which offered sanctuary to such escapees was the Naini asylum at Allahabad where the Rev. Sam Higginbottom (American Presbyterian Mission) was superintendent, of whom many other asylum superintendents wrote angry complaints to the Mission to Lepers. The Superintendent of the Champa asylum complained in 1921: "about 30 people wanted to get married in our Asylum. I married none of them. Consequence?-Off to Higgenbottoms [sic]". ${ }^{64}$ Higginbottom maintained that segregation was simply not enforceable, and ought to be dispensed with: "Lepers who come from asylums where strict segregation is the rule, aver that when young men and women wish to be together, orders or no orders, walls or no walls, they do so."65

Confinement and segregation of the sexes were the major preventive measures of western medicine. Surgical facilities were available in a very few of the larger asylums. Dr Ernest F Neve, a pioneer in nerve stretching, had conducted 270 operations at his asylum in Kashmir by 1889.66 For eye complications, so common in leprosy, there was virtually no facility in the asylums, though patients might be lucky enough to find a hospital willing to perform eye surgery. ${ }^{67}$ In the leprosy asylums in India a lopsided situation developed, with a high degree of interest and investment in experimentation with possible cures for the disease, while basic facilities such as bandaging and care of ulcers, or providing medicines for other ailments were neglected. The overriding interest in a cure for leprosy bred an openness towards Indian medicine. Some of the more popular treatments were based upon rubbing the body with various oils. ${ }^{68}$ The most enduring was that of Chaulmoogra oil, derived from seeds of Taraktogenos kurzii. The high cost and the difficulties in obtaining the oil seem not to have hindered its free use in asylums. It was also used in the treatment of leprosy patients in England. ${ }^{69}$

From asylum records, which offer a grass-roots perspective, there is evidence that medicine for other illnesses was rarely provided until the $1920 \mathrm{~s}$, when what might be termed a cure for leprosy was developed at the Calcutta School of Tropical Medicine, which led to a heightened medical presence in the asylums. In the Leper Asylum at Almora in the United Provinces there were virtually no medical facilities until 1929. The asylum superintendent, the Rev. E M Moffatt (Methodist Episcopal Church), wrote to the Mission to Lepers in August 1919: "Operations, bandaging, relieving pain form a large part of the work of a doctor in an Asylum. Practically none of this is done in Almora."70 At another major centre, the Purulia asylum, medical care from 1915 to 1921 was mostly experimentation with cures at the behest of the Civil-Surgeon. There was hardly any dressing of ulcers until 1926; prior to this, bandaging of ulcers was done near an open drain. In 1927, patients were trained to treat ulcers; in 1930, 49,000 visits for antiseptic dressings were recorded. ${ }^{71}$

64 Letter from P A Penner, Supt. Champa asylum, to Mission to Lepers, 24 Oct. 1921, 106/5, TLM.

${ }^{65}$ Letter from Sam Higginbottom to Mission to Lepers, 28 May 1924, 110/7, TLM.

${ }^{66}$ Lancet, 1889 , ii: 1000.

67 'A case of cataract in a leper: extraction of lens: recovery in seven days', Indian med. Gaz., 1876: 102.

\footnotetext{
${ }^{68}$ The Leprosy Commission Report mentions 11 such oils, op. cit., note 12 above, p. 361 .

${ }^{69}$ Wyndham Cottle, 'Chaulmoogra oil in leprosy', Br. med. J., 1879, i: 968-9.

${ }^{70}$ Letter from E M Moffatt to Mission to Lepers, 28 Aug. 1929, 105/4, TLM.

${ }^{71}$ E B Sharpe, 'Purulia leper colony, 1888-1931', 111/6, TLM.
} 


\section{Sanjiv Kakar}

Several factors converged in the 1920 s to transform conditions in leprosy asylums, and improved care for patients resulted. Developments in medicine in the early decades of the twentieth century initiated a break with the past, and redefined the medical representation of leprosy. Microscopic examination and improved laboratory techniques established that patients in the earliest stages of the disease harboured more bacilli than those in the later stages and were more likely to transmit it, thereby constituting a greater threat to public health. Secondly, the preparation of a new medical treatment held the hope of cure for those patients in the early stages of leprosy. The Calcutta School of Tropical Medicine and Hygiene played a leading role in the development and dissemination of this knowledge to leprosy asylums. Sir Leonard Rogers pioneered an injection preparation of the active agents of Chaulmoogra oil, prepared in $1915 .^{72}$ Rogers summed up the impact of these advances:

From the first I made it clear that I did not claim to cure leprosy in the scientific sense of removing the last lepra bacilli from the body ... I also pointed out the necessity of commencing treatment in a comparatively early stage of the disease to ensure the best results. ${ }^{73}$

The spread of this altered medical perspective to the asylums was slow and uneven, and often agonizing, for acceptance brought into question the logic of the institutions and their practices: commitment to separation, the identification of ulceration and deformity with leprosy, which had strong religious roots, and their traditional role as sanctuaries. Missionary managers of asylums were caught between medicine and the religious character of their establishments. The Rev. J N Hollister, superintendent of the Almora asylum, wrote to the Mission to Lepers in 1930:

It seems to me that there can be no question of our course. It must be to serve as many whom we can cure, and medically serve, rather than to shelter for the rest of their lives those who have been mutilated in body . . but in whom the disease is no more active. ${ }^{74}$

W H P Anderson, the General Secretary to the Mission to Lepers, rejected this attempt to undermine the traditional function of the asylum:

Can your Mission and our own, as Christian organisations, be content to see these people without the help that should be given to them in Christ's Name? . . . it is fundamental to our working that we should, in so far as we are able, care for destitute and suffering lepers irrespective of whether they offer hope of response to present-day medical treatment. ${ }^{75}$

He also referred to the expectations of the donating public in Britain. The decision of the government to make grants only for patients who might be cured put greater pressure on asylums to change from their traditional role as sanctuaries. ${ }^{76}$

The task of dissemination of the new medicine for leprosy was given to Dr E Muir, whom Rogers left as his successor at the Calcutta School of Tropical Medicine when he

\footnotetext{
72 Experiments with injections of Chaulmoogra oil were conducted in several countries; for an account of research at the Calcutta School of Tropical Medicine see Major-General Sir Leonard Rogers, Happy toil: fifty-five years of tropical medicine, London, Frederick Muller, 1950, pp. 190-4; Power, op. cit., note 5 above, pp. 143-83.

${ }^{73}$ Rogers, op. cit., note 72 above, p. 193.
}

\footnotetext{
74 Letter from Hollister to Mission to Lepers, 15 Dec. 1930, 105/4, TLM.

75 Letter from Anderson to Hollister, 8 Jan. 1931, 105/4, TLM.

${ }^{76}$ The Madras government issued such an order in 1938; for the plight of 280 patients following their eviction from the Lady Willingdon Leper Settlement in 1939 see the Mail (Madras), 16 Aug. 1939.
} 
returned to England. Asylum after asylum adopted these medical practices, usually after a personal visit by Dr Muir, or after a training stint in Calcutta. This was the case at the Travancore asylum in 1920, the Champa asylum in 1921, and the Subathu asylum (since 1913 run by the Brethren Mission) which Muir visited in $1925 .{ }^{77}$ A piecemeal adoption of medicine commonly occurred. At the Travancore asylum (Church Missionary Society), hypodermic treatment was initiated in 1920 . But due to its proximity to private homes, the asylum was under pressure from the municipal council, which led to a tightening of confinement following a recommendation by the court physician, Dr Simpson. ${ }^{78}$ Asylums such as Purulia offered out-patient services, yet continued to confine and segregate inmates. In 1931 over a thousand out-patients were treated weekly. ${ }^{79}$ Many missions set up clinics and dispensaries exclusively for leprosy in outlying districts. In Bengal the Church Missionary Society had dispensaries at Manicktolla, where 11,036 injections were given in $1931{ }^{80}$ But calls for segregation continued. The Statesman carried a report in January 1933 calling for compulsory segregation of all patients, ironically at the inauguration of an out-patient centre at Manicktolla. ${ }^{81}$

The reaction of patients to this new medication, despite the fact that asylums did not easily drop their penal characteristics, reflected a desire for cure that overrode other issues. Dr Muir wrote to the Inspector-General of Civil Hospitals in 1927 that "the large majority of the inmates are so favourable [sic] impressed with the treatment that they complained bitterly the other day when the medicine ran short and the injections had to be suspended for 10 days". 82 The patients' responses to asylums and the medicine they provided need to be looked at in the context of both changes within the institutions, and continuing public prejudice. ${ }^{83}$ For patients in advanced stages of the disease medication might not cure, but the need for sanctuary remained. The Indian Express reported in April 1939 a "Lepers' strike in Cochin", by two patients, "refusing to move unless they were provided shelter and cared for at the Leper asylum at Adoor". 84 They were successful.

\section{Conclusion}

Medical intervention in the management of leprosy during the colonial period was extremely limited, touching only a small fraction of the patients. This was in spite of a lack of opposition by the Indian elites to governmental efforts, which deprived the colonial state of its long-standing excuse that public health measures were inhibited by Indian hostility. None the less, as Philippa Levine writes, there remains "a critical and urgent need to unpack, too, the complexities and ambiguities of colonial rule in its varying contexts". ${ }^{85}$ This study has attempted to contribute to this, and to fill in a historiographic gap in the case of leprosy. Some of the themes explored elsewhere have an echo here, such as the movement of medical ideas from the imperial metropolis to the colonial peripheries,

\footnotetext{
${ }^{77}$ For the Hospital for Lepers, Dichpalli, Hyderabad, see Lancet, 1925, ii: 373-5.

${ }^{78}$ Durbar physician's report, 1920, 105/2, TLM.

79 'Purulia Leper Hospitals: annual medical report 1931', 111/7, TLM.

${ }^{80}$ Medical report for the C.M.S. Leper

Dispensaries, 106/1, TLM.

81 Statesman, 27 Jan. 1933.
}

${ }^{82}$ Letter from Muir to Inspector General Civil Hospitals, 29 April 1927, 111/8, TLM.

${ }^{83}$ See the Englishman, 16 Jan. 1924; the Pioneer, 28 Oct. 1930.

${ }^{84}$ Indian Express, 21 April 1939.

85 Philippa Levine, 'Venereal disease, prostitution, and the politics of empire: the case of British India', J. Hist. Sexuality, 1994, 4(4): 579-602, on p. 602. 
the influence of global factors on colonial health policy, and the relationships within the colonial order between medicine and officialdom, or between westerners and collaborating Indian elites. ${ }^{86}$ What I have tried to do is to follow the route of western medical treatment of leprosy from its origins to its contact with the leprosy patient; to discuss what influenced governmental verdicts on leprosy, and then to see how these were mediated by the specific nature of the medical institutions involved; finally, how patients themselves could be agents who influenced medical practice, rather than passive recipients. The wide gulf between the Leprosy Commission on the one hand, and what actually took place in the leprosy asylums, also illustrates the transformations which medicine underwent along the way.

This study has considered too the medical practices of Christian missionaries. Leprosy asylums run by the state were not substantially different from those run by missionaries, except for the mandatory religious teaching, which underlined the interpenetration of religious, medical and public notions of leprosy. From the 1920s, conflicts between religion and medicine were felt in the asylums; but, on the whole, there existed for leprosy a consensus which overrode differences and which cut across the colonial divide. This was another sign that leprosy was unique, and this uniqueness calls for prudence in making general observations on the medical practices of Christian missionaries. But the study of leprosy does make glaringly visible the role of religion in medical practice, and this opens up a field of study which has remained underdeveloped so far. Especially in the case of diseases which were charged with religious connotations for Indians, like smallpox, for instance, which many Hindus believed to be the visitation of the Mother Goddess, the experience of missionary medicine followed a course distinct from that of secular medicine.

All of this points to a pluralism of western medicine in India, which has generally been smothered. Sumit Sarkar has discussed the legacy of Edward Said on modern Indian historiography: "The homogenizations to which the Saidian framework seem particularly prone are related, I feel, to major problems in its conception of power ... There is ... the tendency . . . to ascribe virtually unlimited domination to ruling forms of powerknowledge. ${ }^{, 87}$ Western medicine in India was not a monolith, nor were Indian patients necessarily passive recipients; this too runs counter to the Saidian orthodoxy; Sarkar adds, "assumptions of total domination foreclose investigations of elements of resistance or partial autonomy, and rob subordinate groups of agency". ${ }^{88}$ Western medicine in India was not necessarily perceived in binary terms, to be accepted or rejected. Leprosy patients modified medical practices such as confinement and sexual segregation. There were waves of unrest in many asylums in the 1930s and 1940s, a novel development produced partly by the transformed medical situation in the 1920s, and these further modified the culture of the asylum. Protest was not directed at medical practice, but at such factors as food shortages (at the Naini asylum in 1934); and these specific grievances did not necessarily lead to a total rejection of western medicine. At the Ramachandrapuram asylum, unrest began in 1938, with some patients protesting against its religious character:

\footnotetext{
${ }^{86}$ See Arnold, op. cit., note 2 above; Harrison, op. cit. note 2 above.

${ }^{87}$ Sumit Sarkar, 'Orientalism revisited: Saidian frameworks in the writing of modern Indian
}

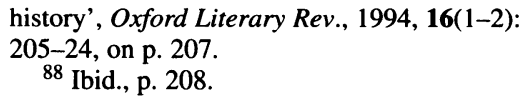


the medical officer of the asylum wrote: "they were inducing our Christian inmates to wear caste-mark and not to attend Church services". ${ }^{89}$ Unrest dragged on for several months, and the inmates went on strike in March 1939. Apprehension by the missionary management (Canadian Baptist Mission) that the Christian character of the asylum was being undermined (elected provincial governments had controlled health matters since 1935), the support by the Collector for the patients, and the publicity given to the patients' strike, all contributed to the tense situation. ${ }^{90}$ The management resorted to closure of the asylum, and re-admitted only patients who agreed to submit to the rules; for this a new relationship had to be forged, which included a perspective on the rights of the patients, a far cry from compulsory confinement: "This dual freedom must be established. It is free for patients to come, and to leave; it must also be free for the management to receive and discharge freely."91

Western medicine for leprosy has undergone several upheavals during this century. From the 1940s, the sulfone treatment replaced the hypodermic injections of Chaulmoogra oil; this formed the basis of the Government of India's Leprosy Control Programme launched in 1950. Vastly more effective than earlier treatments, sulfone monotherapy was however merely bacteriostatic. The next major shift occurred in 1986, when a phased introduction of multi-drug therapy for leprosy began. At last western medicine had produced a cure, which in most cases would be effective with six to eighteen months of treatment. ${ }^{92}$ This was the basis of the new National Leprosy Eradication Programme, which envisaged the elimination of the disease from India by the year 2000 . Now voluntary agencies, including missionaries, were to work in concert with the state machinery.

An oral history project was conducted in 1991-92 in villages in some leprosy endemic districts of India. ${ }^{93}$ This complemented the archival historical study, for it moved outside the reach of the colonial state into regions which had been untouched by western medicine for leprosy. Interviews with patients, villagers, and health workers yielded much information on indigenous perceptions of the disease and on the reception of western medicine, all of which underlined pluralism. Perceptions of leprosy varied considerably, even in villages close to each other; in some it was regarded as an illness, in others as a curse, in others both of these notions co-existed. Similarly, attitudes on causation, transmission and cure also varied. The only common factor was a widespread prejudice against leprosy sufferers. Initially, village communities, including patients, were reluctant to accept the bacteriological view of leprosy as a curable disease, but gradually the visibility of cured patients undermined traditional beliefs. Patients who were detected early and had no deformities were more easily accepted back into the fold, but in many cases cure was not accepted so long as the tell-tale physical deformities remained, for these were the signifiers of leprosy, not laboratory reports on the bacteriological status of the patient. Western medicine was most successfully introduced by dialogue and education, rather than coercion.

\footnotetext{
${ }^{89}$ Letter from Dr D L Joshee to Mission to Lepers, 23 Oct. 1938, 113/1, TLM.

${ }^{90}$ See the Hindu 25 March 1939.

91 Letter from Donald Miller to Mission to Lepers, 9 April 1939, 113/1, TLM.
}

\footnotetext{
92 A useful text is Leprosy for medical practitioners and paramedical workers, Basle, CibaGeigy, 1986.

93 For a detailed account, see Kakar, The Patient, and 'Leprosy in India', both op. cit., note 4 above.
} 


\section{Sanjiv Kakar}

Oral history cannot extend back into the colonial period, but it can provide pointers and useful correctives. Similarly, the historical study of leprosy is not without relevance to the contemporary medical effort for eradication of leprosy in India, and the well-being of some three million patients. The experiences of western medicine in India, in all their richness and complexity, need to be called up if modern treatments are to be widely accepted. 